\title{
Informacje dla autorów
}

1. Linguistica Copernicana publikuje artykuły w języku polskim, w innych językach słowiańskich, a także w języku angielskim, niemieckim i francuskim.

2. Prosimy autorów o przysyłanie tekstów przeznaczonych do druku wyłącznie w wersji elektronicznej w postaci dwóch plików, z których jeden należy zapisać w formacie *.doc, drugi w formacie *.pdf. Autorzy, którzy stosują w tekście fonty specjalne, są proszeni o ich dołączenie. Teksty należy przesłać jako załączniki do e-maila na adres lincop@umk.pl.

3. Objętość artykułów przesyłanych do druku nie powinna przekraczać 14 stron (łącznie ze streszczeniem, przypisami i bibliografia) w formacie A4 (około 25000 znaków ze spacjami wg MS Word: Plik - Właściwości - Statystyka).

Objętość recenzji nie powinna przekraczać 7 stron w formacie A4 (około 12000 znaków ze spacjami).

4. Imię i nazwisko autora

Tekst powinien zawierać $\mathrm{w}$ lewym górnym rogu imię i nazwisko autora, jego adres e-mail oraz nazwę reprezentowanego ośrodka naukowego (czcionka Times New Roman 12 p.).

5. Tytuł artykułu: środek, druk półtłusty (bold), czcionka 12 p.

6. Słowa klucze: 4-6, umieszczone pod tytułem, justowanie do dwóch stron.

7. Tekst

Czcionka: Times New Roman 12 punktów.

Interlinia: 1,5 wiersza. 
Marginesy: lewy margines $3 \mathrm{~cm}$, pozostałe $2,5 \mathrm{~cm}$.

Tabulator: $1,0 \mathrm{~cm}$.

Justowanie do dwóch stron.

Ujednolicona i ciagła numeracja stron (paginacja).

Tekst zapisany w formacie *.pdf i *.doc (Word 95 lub wyższy + fonty specjalne, wprowadzone przez Autora).

Omawiane w artykule wyrazy, zwroty, zdania oraz zwroty obcojęzyczne należy wyodrębniać kursywą.

Objaśnienia znaczeń wyrazów należy podawać w łapkach.

Cytaty należy umieszczać w cudzysłowie.

Do wyróżnień tekstowych należy stosować druk rozstrzelony.

Prosimy nie stosować spacji w celu wyrównywania tekstu, nie zostawiać pustych wierszy, nie dzielić wyrazów, nie stosować żadnego specjalnego formatowania.

\section{Streszczenia}

Prosimy o dołączenie do artykułu krótkiego streszczenia wraz z tytułem artykułu (do 900 znaków, około pół strony): a) w języku angielskim, niemieckim, francuskim lub rosyjskim, jeśli tekst artykułu jest napisany w języku polskim, b) w języku polskim, jeśli tekst artykułu jest napisany w innym języku niż polski. Jeżeli streszczenie jest obcojęzyczne, należy przesłać jego polskojęzyczną wersję. Streszczenie powinno być umieszczone po bibliografii. Recenzje nie wymagają streszczeń.

9. Wykresy, tabele itp. prosimy dołączać w osobnych plikach. W tekście należy wyraźnie zaznaczyć miejsce, w którym mają być one umieszczone.

Obowiązuje numeracja ciągła wykresów, tabel itp. w obrębie całego tekstu.

Opis wykresów, tabel itp. powinien wyglądać następująco:

Tabela 1. Formanty tworzące nazwy czynności (umieszczone nad tabelą)

Źródło: opracowanie własne (umieszczone pod tabelą).

10. Przypisy (czcionka Times New Roman 10 punktów, interlinia 1,5, odnośniki w indeksie górnym) należy umieszczać na dole strony, nie na końcu tekstu. Obowiązuje numeracja ciągła przypisów w obrębie całego tekstu. Prosimy o ograniczenie liczby przypisów na rzecz cytowania w tekście głównym, zgodnie z następującą konwencją: R. Laskowski (1998: 225-226). 


\section{Bibliografia}

Nazwisko autora należy zapisywać kapitalikami. Nazwiska autorów oraz tytuły książek i artykułów w językach słowiańskich mających alfabet oparty na cyrylicy podajemy w oryginalnej ortografii.

Przykłady opisów bibliograficznych:

a) monografie

BogusŁawski A., 2004, Aspekt i negacja, Warszawa: Wydawnictwo Takt.

Buttler D., 2001, Polski dowcip językowy, Warszawa: Wydawnictwo Naukowe PWN.

b) artykuły w wydawnictwach zwartych

JADACKA H., 2003, Zagadnienie motywacji słowotwórczej w opisie gniazdowym, w: M. Skarżyński (red.), Stowotwórstwo gniazdowe. Historia. Metoda. Zastosowania, Kraków: Księgarnia Akademicka, s. 29-40.

c) artykuły w wydawnictwach ciagłych

WierzBICKa A., 1966, Czy istnieją zdania bezpodmiotowe, Język Polski XLVI, s. $177-196$.

d) opis bibliograficzny dokumentów elektronicznych powinien zawierać dodatkowo informacje o typie nośnika (w nawiasach kwadratowych), np. [CD-Rom], [online]. Opis dokumentów dostępnych on-line powinien zawierać adres, pod którym można znaleźć pozycję w sieci, oraz datę dostępu w nawiasach kwadratowych.

W wypadku powoływania się na stronę internetową podajemy adres strony oraz datę dostępu.

KopalińsKi W., 1998, Stownik wyrazów obcych i zwrotów obcojęzycznych [CD-ROM], PRO-media CD, Łódź.

Widawski M., 1998, Stownik polskiego slangu [online], http://www.univ.gda. pl/slang/, [18.10.2006].

http://slowniki.pwn.pl/poradnia/lista.php?szukaj=dywiz\&kat=18, [20.01.2006].

12. Prace są recenzowane jako teksty anonimowe. Recenzje są dla autorów również anonimowe. 